\title{
Wymowa sceniczna w śpiewie klasycznym
}

\section{Diction in classical singing}

\author{
Matgorzata Nabiatek \\ INSTYTUT JEZZYKOZNAWSTWA, UNIWERSYTET IM. ADAMA MICKIEWICZA \\ AL. NIEPODLEGŁOŚCI 4, 61-874 POZNAŃ
}

\begin{abstract}
This article is to explain why listeners often find it hard to understand the opera singing, and to emphasize the importance of singers' and conductors' awareness of diction in singing. The author defines the term "diction in classical singing", what exactly the subject of this discipline is and what problems and difficulties may both singers and diction coaches encounter in the process of preparing the textual layer of a musical piece.
\end{abstract}

\section{Co to jest wymowa sceniczna?}

Słynna postać teatru, Constant Benoit ${ }^{1}$ powiedziat: „Życie codzienne przeniesione na scenę wywohje takie samo wrażenie, jak statua normalnego wzrostu postawiona na wysokiej kolumnie, która traci dla obserwatora swa naturalnq wielkość." [za: Czechow, 1995]

Reguła opisana przez Benoit jest jedną z głównych zasad rządzących na deskach teatralnych. W kontekście wymowy podyktowana jest ona takim bardzo ważnym czynnikiem jak styszalność. Aktor chcący dobrze wypowiadać swą kwestię musi być słyszalny - tekst musi docierać do ucha słuchacza siedzącego w najdalszym rzędzie widowni. Jest to możliwe dzięki prawidłowej fonacji i emisji głosu. Drugim, równie ważnym czynnikiem, jest wyrazistość (co można określić jako stosunkowo wydłużone iloczasy wszystkich głosek), a co za tym idzie, zrozumienie przez publiczność mówionego tekstu - tu odpowiedzialna będzie prawidłowa artykulacja głosek oraz poprawne stosowanie zasad wymowy scenicznej. [Pawłowski, 2005]

Co dalej odróżnia wymowę sceniczną od wymowy spontanicznej (codziennej), to brak cech regionalnych, dialektowych oraz kolokwialnych w tekstach neutralnych. [Nowakowski, 1997] W tekstach gwarowych, żargonowych czy dialektowych będących kreacją artystyczną, również

$1 \quad$ Constant Benoit $(1841$ - 1909) - francuski aktor i członek Comédie Française, autor m.in. L'Arte et le Comédien [Czechow, 1995] 
obowiązywać będą określone przez wymowę sceniczną zasady łączenia głosek i wyrazów stosowne do danego stylu.

Biblia polskiej wymowy scenicznej, Prawidta poprawnej wymowy polskiej Zenona Klemensiewicza, uwzględnia dwa stopnie poprawności mowy polskiej: potoczny i sceniczny. W dzisiejszych czasach jednak, być może ze względu na dynamiczny rozwój oraz dużą dostępność przeróżnych środków przekazu audio- i audiowizualnego, można zaobserwować większe rozwarstwienie w polszczyźnie, niż jak to było za czasów Klemensiewicza, czyli na początku dwudziestego wieku. Danuta Michałowska w $O$ podstawach polskiej wymowy scenicznej wyraźnie rozróżnia trzy stopnie poprawności polszczyzny kulturalnej:

„(...) potoczny, który częstokroć daleko odbiega od poprawności szkolnej, zwłaszcza w zakresie dopuszczalnych uproszczeń (nie bierzemy tu pod uwagę słownictwa), szkolny, czyli zasadniczo poprawny pod względem gramatycznym i wymawianiowym, wreszcie sceniczny, którego specyfika nie polega na poprawności, ale głównie na szczególnej wyrazistości.”

Wymowa sceniczna zatem nie wyznacza poprawności reguł gramatycznych, gdyż opiera się głównie na tekstach danych (poezja, scenariusze itp.), a skupia się na prawidłowym tych tekstów zaprezentowaniu.

Często można również napotkać na wymienne stosowanie dwóch terminów: dykcja i wymowa sceniczna. W moim przekonaniu to dwa różne pojęcia, gdzie $d y k c j e ̨$ można zdefiniować jako zasady poprawnej artykulacji głosek przy prawidłowej emisji głosu; natomiast wymowę sceniczną, idąc dalej za cytowaną myślą Michałowskiej, jako zbiór zasad poprawnego łączenia wyartykułowanych głosek i słów obowiązujący na scenach teatralnych i estradach.

(Mylący może być również, używany w niniejszej pracy, termin w języku angielskim diction, określający wymowę sceniczną.)

\footnotetext{
Wymowa sceniczna określi, jak wymawiając należy poprawnie odróżnić następujące frazy (zasłyszane nieporozumienia językowe):

Danuta Stenka / Danuta stęka

Irenka / i ręka

syn Kopa / synkopa

To są siatki / to sąsiadki

I chciała / ich ciała

3 nastolatki / trzynastolatki

Celnie trafia / cel nie trafia

Będą to zasady poprawnościowe dotyczące ruchomej samogłoski, upodobnienia pod względem miejsca artykulacji oraz iloczasów sterowanych przez względy semantyczne, akcenty i zasady łączenia postępowego i wstecznego.
} 
Wydaje się jednak, że ów trójpodział proponowany przez Danutę Michałowską obecnie jest niewystarczający i wymowę sceniczną należałoby podzielić dodatkowo na wymowe telewizyjna/publiczna używaną $\mathrm{w}$ mediach, serwisach informacyjnych, przez polityków i spikerów, która wymaga poprawności jak wymowa szkolna, jednak ze zwróceniem uwagi na nieco większą wyrazistość; oraz wymowę teatralna używaną na deskach teatrów

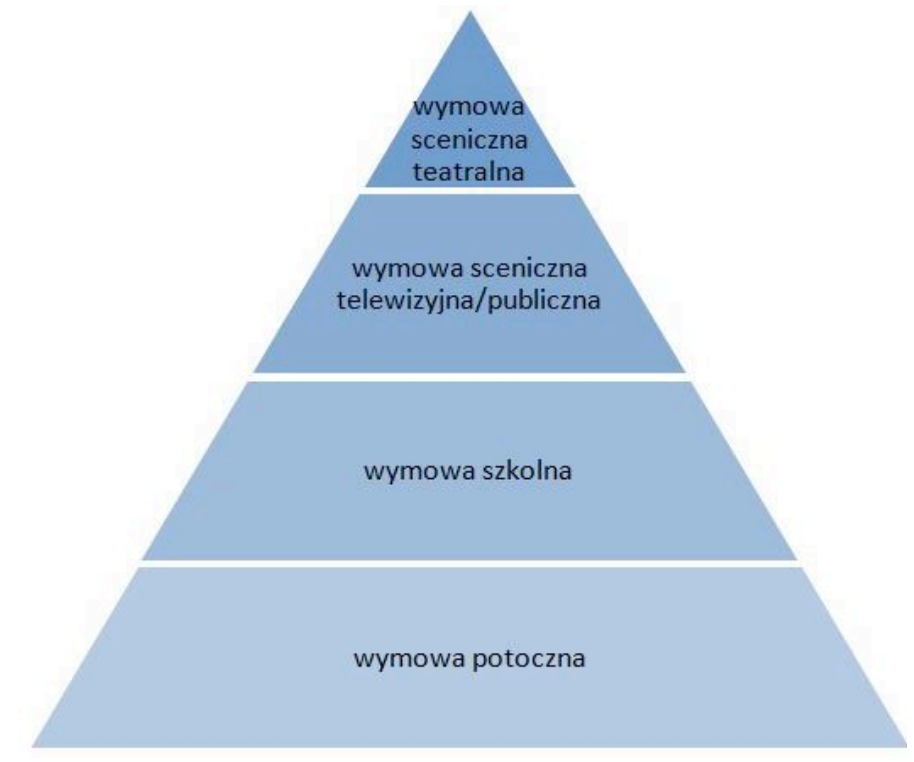

Ryc. 1.1 Stopniowanie poprawności polszczyzny kulturalnej

Żródło: opracowanie własne, na podstawie: Michałowska, O podstawach polskiej wymowy scenicznej, 1994

dramatycznych, muzycznych i operowych do prezentowania przede wszystkim gotowych tekstów artystycznych, gdzie czynnikiem absolutnie nadrzędnym jest wyrazistość. (Ryc. 1.1)

Istnieje cienka granica pomiędzy wymową sceniczną i jej wyrazistością a hiper- artykulacją. Ta ostatnia jest niedopuszczalna i świadczy może nie o braku świadomości zasad wymowy scenicznej, ale wyczucia i dobrego smaku. Zbyt świszczące /s/, zwłaszcza wygłosowe, nadmierne wydłużanie iloczasów głosek czy dodawanie szwy /ə/ (epenteza) w zbitkach spółgłoskowych takich jak /tərə'vaţ/ <trwać>, jeżeli nie wymaga tego rola, w którą wciela się artysta, wpływają niekorzystnie na odbiór tekstu i mogą denerwować słuchacza.

Podobnie będzie z obcojęzyczną wymową sceniczną: trenerzy dykcji i nauczyciele śpiewu wyraźnie podkreślają odróżnienie wymowy teatralnej od wymowy codziennej języków. Wyłaniają dodatkowe zasady i uwagi, które pomagają w osiągnięciu specyficznej dla sceny i teatru wyrazistości. Zatem powyższy schemat (Ryc.1.1) może posłużyć jako przedstawienie ogólnych tendencji w ukształtowaniu i stopniowaniu wymowy kulturalnej języków. 


\section{Rola wymowy scenicznej i oczekiwania wobec artystów}

Idąc tropem historii kształtowania się zasad poprawnościowych (najwcześniejsze badania dotyczące brzmienia języka pochodzą z Indii z około $\mathrm{V}$ wieku p.n.e. - recytacje świętych hymnów wedyjskich spełniały tylko wówczas swoją funkcję religijno-magiczną, gdy były wypowiadane poprawnie językowo) [Milewski, 1975] można stwierdzić, że wymowa sceniczna, jako zbiór takich zasad, jest tworem sztucznym - gdzie artysta uczy się używać tychże zasad poprawnościowych; oraz celowym - służy jak najlepszemu przekazowi tekstu i jego treści. [Michałowska, 1994]

Rolę wymowy scenicznej w kreacji artystycznej można rozumieć na różne sposoby: a) jako część zasady decorum - kreacja sceniczna wymaga najwyższego traktowania i szacunku również poprzez czystość i poprawność wymowy; b) jako część warsztatu artystycznego umożliwiającą komunikację pomiędzy artystą a publicznością, jako oznaka przygotowania, czyli okazanie szacunku wobec publiczności; c) np.: w języku angielskim poprzez silną dialektyzację oraz ostry podział na różniące się od siebie standardy możliwy jest dodatkowy zabieg w postaci zaznaczenia szlacheckiego pochodzenia bohatera (nawiązanie do decorum), a dodatkowo płynna i poprawna wymowa ma symbolizować siłę i autorytet szlachetnie urodzonego - i jest to np. Received Pronunciation lub Mid-Atlantic na tle American Standard (np.: Lord Vader i Księżniczka Leia w Gwiezdnych wojnach wypowiadają swoje kwestie w MA, film 300 jest amerykańską produkcją, gdzie Spartanie rozmawiają w RP). [LaBouff, 2008]

W odniesieniu głównie do języka angielskiego, wyraźnie o roli poprawnej wymowy traktują takie znane filmy, jak "My Fair Lady", "Singing In the Rain" (Deszczowa piosenka), czy “The King's Speech" (Jak zostać królem). Odpowiednio: awans do wyższej warstwy społecznej; klasa i warsztat artysty: aktora, wokalisty (gdzie główni bohaterowie, ćwiczą dykcję do pierwszego filmu dźwiękowego), siła i autorytet króla, to główne cele do osiągnięcia poprzez ćwiczenie płynnej i poprawnej wymowy.

\section{Podejście artysty do wymowy scenicznej}

Coraz bardziej przyspieszający styl życia w dzisiejszych czasach często nie pozwala widzowi zapoznać się z librettem i/lub literaturą dotyczącą treści przedstawienia, dlatego zadaniem aktora/śsiewaka jest zadbanie o jak najdoskonalsze dostarczenie treści zawartej w partii czy roli za pierwszym razem. [LaBouff, 2008]

Aby tak się działo, artysta już na etapie studiów i wstępnego szkolenia się do zawodu powinien wykształcić w sobie zespół przyzwyczajeń i niezbędnych rutyn dotyczących sposobu pracy nad rolą, czyli tzw. warsztat pracy. Dbałość o szczegóły oraz dostrzeganie potrzeby ciągłego treningu i specjalistycznych konsultacji niewątpliwie świadczą o klasie artysty.

Bardzo często artyści, a szczególnie śpiewacy, posiłkują się jedynie swoją intuicją $\mathrm{w}$ kwestiach wymowy scenicznej (zwłaszcza w języku 
ojczystym), co w wielu wypadkach nie zastąpi znajomości tychże zasad oraz pełnej świadomości zjawisk, jakie mają miejsce podczas śpiewu. Co za tym idzie, ci sami śpiewacy nie uznają potrzeby ustawicznego poszerzania swojej wiedzy oraz ćwiczenia wymowy pod okiem instruktora. [LaBouff, 2008] Winy można by również upatrywać w systemie edukacji muzycznej i luce w programach nauczania (przedmiot „Wymowa sceniczna w śpiewie” jako taki w Polsce nie istnieje, występuje rozproszony, częściowo, jako dodatek do innych przedmiotów)

$\mathrm{W}$ odniesieniu do wymowy scenicznej $\mathrm{w}$ języku obcym, jest to wskazówka dla wokalistów posiłkujących się w opracowywaniu wymowy nagraniami utworów wokalnych $\mathrm{w}$ wykonaniu śpiewaków, dla których dany język jest ojczysty. Należy zachować tu pewną dozę rezerwy i sceptycyzmu, zwłaszcza $\mathrm{w}$ przypadku artystów mniej u/znanych na świecie, oraz wysuwać wnioski na podstawie większej ilości wykonań (co najmniej trzech).

Jak już zostało wspomniane $\mathrm{w}$ punkcie 1.1, trenowanie oraz przygotowanie wymowy tekstu wypowiadanego lub śpiewanego na scenie, jest nie tylko określeniem klasy artysty i jego warsztatu, ale przede wszystkim wyrazem szacunku dla zgromadzonej w teatrze publiczności, jak i pozostałych twórców wystawianego dzieła.

\section{Wymowa sceniczna w śpiewie}

Tak samo, jak tekstem mówionym na scenie rządzą zasady wymowy scenicznej, tak tekstem śpiewanym na scenie będą rządzić zasady wymowy scenicznej w śpiewie.

Zgodzić się można z Jerzym Bartmińskim [1993], iż „(...) w śpiewanym tekście strona dźwiękowa słów ulega rozwinięciu i przystosowaniu do funkcji melicznych, strona semantyczna zaś - przythumieniu i pewnej degradacji(...)." Jednak to zjawisko powinno podziałać na artystę raczej jak wyzwanie, a nie wymówka.

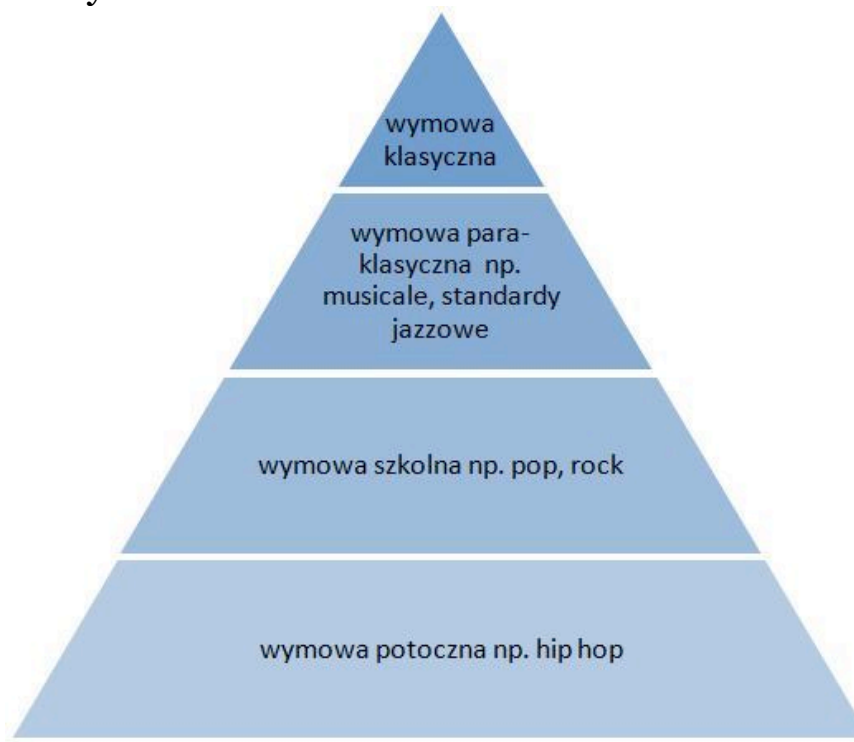

Ryc. 1.2 Stopniowanie wymowy scenicznej w śpiewie 
Stopniowanie wymowy w śpiewie (Rycina 1.2) przebiega podobnie do wymowy w języku mówionym. Jednak co ważniejsze, specyfika i gęstość stratyfikacji wskazuje na potrzebę niezależnego traktowania tej dziedziny (wymowy w śpiewie) zarówno w analizach naukowych, jak i działalności artystycznej. Podczas gdy każdy z poziomów wymaga większej wyrazistości, różnica między nimi polegać będzie na stopniu odpotocznienia tekstu i wymowy, idąc w górę piramidy (Ryc. 1.2). Styl potoczny dopuszczalny jest np. w utworach hiphopowych czy reggae (slangi, języki kreolskie itp.); piosenki popowe czy rockowe reprezentują już wyższy poziom kultury języka zarówno w tekstach, jak i w wymowie; jeszcze wyższy poziom zachowany jest $w$ musicalach, standardach jazzowych, również w większości klasycznych ballad soulowych i R\&B; natomiast najwyżej sklasyfikowana jest tu wymowa sceniczna - klasyczna w utworach operowych, operetkowych, oratoriach, kantatach czy pieśniach artystycznych. W powyższym zestawieniu nie zostały wymienione wszystkie możliwe rodzaje muzyki - wybrane zostały reprezentacyjne rodzaje utworów wokalnych w ujęciu idealistycznym.

Poprawna i prawidłowa artykulacja zwłaszcza w śpiewie klasycznym jest istotnym elementem uzyskania pełnego efektu estetycznego, co potwierdza literatura wokalistyczna. [Pawłowski, 2010] Większa część zasad wymowy scenicznej w śpiewie opiera się na zasadach wymowy scenicznej mówionej. W śpiewie jednak wytworzyły się dodatkowe reguły, co spowodowane zostało nałożonym dodatkowym wymiarem muzycznym, który determinuje tu większość zjawisk artykulacyjnych. Cechy prozodyczne mowy ulegają w śpiewie rozwinięciu lub zmodyfikowaniu przez prozodię muzyczną, która bardzo często utrudnia artykulację i wydobycie treści z tekstu np. poprzez niezgodność akcentów muzycznych z językowymi czy długie wartości nut i wydłużone iloczasy głosek.

Aby tekst śpiewany stał się w pełni zrozumiały dla słuchacza, oprócz perfekcyjnej techniki niezbędne jest zastosowanie zasad wymowy scenicznej w śpiewie wyłonionych na podstawie połączenia zasad wymowy scenicznej i natury zjawisk towarzyszących przeniesieniu tekstu na linię melodyczną. (Precedensowym przykładem na potrzebę połączenia tych dwóch elementów jest przypadek jednej z najwybitniejszych śpiewaczek wszechczasów, La Stupendy - Joan Sutherland (1926-2010): dysponowała ona niespotykaną techniką, skalą i barwą oraz wyrównaniem rejestrów, natomiast zawsze krytykowana była za fatalną wymowę i brak zrozumiałości tekstu.)

Dodatkowy wymiar muzyczny, a co za tym idzie takie czynniki jak określone wysokości dźwięków, rytm, dynamika, towarzyszenie akompaniamentu, wysokość tessitury, zjawisko legato i in., powinny oznaczać jeszcze większą dyscyplinę wymawianiową niż w tekście mówionym. Zasady zostają tu poszerzone o dodatkowe reguły - są to często triki wynikające ze specyfiki śpiewu, czyli potrzeby większej wyrazistości np. ze względu na wymóg przebicia się przez brzmienie orkiestry, dłuższego czasu na artykulację głosek, czy dużego ambitusu dźwiękowego - nienaturalnego dla mowy. 
Takim przykładowym trikiem może być zastąpienie spółgłoski /m/ przez delikatne /b/ podczas śpiewu w wysokim, niewygodnym rejestrze, w celu ułatwienia produkcji dźwięku; lub np. gdy fraza kończy się domknięciem sylaby spółgłoską /p/ przy dużej dynamice, możliwe jest dla ułatwienia artykulacji i większej wyrazistości zastąpienie jej ubezdźwięcznionym /b/. Należy jednak zwrócić uwagę, że tego typu zabiegi muszą być stosowane ostrożnie i z wyczuciem, tak, aby publiczność nie była świadoma tych czynności. [LaBouff, 2008]

Śpiew klasyczny występuje nierozłącznie $\mathrm{z}$ wymową sceniczną. Oznacza to, że śpiewak klasyczny chcąc wykonać utwór niestandardowy np. pieśń ludową, powinien zastosować zasady wymowy scenicznej w śpiewie, pomimo występowania w tekście zwrotów potocznych albo regionalizmów czy też pomimo popularnej tradycji wykonania danego utworu. W przeciwnym wypadku naraża się na śmieszność przez zmieszanie wysokości stylów. Dlatego też wszelkie odstępstwa od zasad wymowy scenicznej w śpiewie mogą być jedynie zabiegiem świadomym i celowym, podanym do decyzji kierownika muzycznego. Takim umyślnym zabiegiem w wymowie angielskiej będzie użycie dialektów (np. w poezji szkockiej w Songs of Travel Ralpha Vaughana Williamsa), stylizacji (np. akcent portorykański w musicalu West Side Story Leonarda Bernsteina) czy wtrętów dla efektów humorystycznych (np. jak Kristin Chenoweth w roli Kunegundy w Kandydzie również Bernsteina).

\section{Dlaczego często nie rozumiemy tekstu śpiewanego?}

Język to tancerz jest nad tancerze Każdy to przyzna i przyzna szczerze, Że ten języczek, oj, bez pamięci,

To sie wywija, kurczy, to kręci, Raz jest podłużny, raz w trąbę zwija,

Raz jest jak igła, a raz jak narty, Dhugi, Wypukty, Wklęsty, Rozwarty Ewa Morkowska Katedra Foniatrii, UMFC (tekst do badania wyrazistości mowy)

Przy sprawnie działających aparatach artykulacyjnym, fonacyjnym i oddechowym u zdrowego śpiewaka, czynnikami mającymi wpływ na zrozumiałość tekstu śpiewanego są m.in.: a) akustyka pomieszczenia, b) poziom techniki wokalnej, c) wysokość tessitury, w jakiej realizowany jest tekst, d) kierunek odbioru, e) głośność (dynamika) [Pawłowski, 2005], f) cechy artykulacyjne języka oraz g) prawidłowa artykulacja i stosowanie zasad wymowy scenicznej h) inne.

Czynniki te w odmianie niekorzystnej, i dodatkowo łącząc się, mogą wręcz uniemożliwić zrozumienie tekstu śpiewanego. 
Ad a) Na akustykę danego pomieszczenia wpływa jego wielkość, kształt i wystrój [Pawłowski, 2005], a także liczebność zgromadzonej publiczności często po zapełnieniu widowni sala koncertowa wygłusza się, a wrażenia z prób akustycznych stają się nieprzydatne lub konsternujące dla śpiewaka.

Dzieje się tak, gdy część fal emitowanych przez śpiewaka nie dociera bezpośrednio do ucha słuchacza, a odbija się o przeszkody i dochodzi do słuchacza z opóźnieniem. Zjawisko pogłosu (np. w kościołach czy dużych salach) wzmacnia słyszalność, ale zniekształca wyrazistość. [Pawłowski, 2005] Dlatego np. w salach bez pogłosu śpiewak powinien wziąć pod uwagę stopień słyszalności, czyli odległość, jaką musi pokonać wyemitowany dźwięk pomiędzy sceną a ostatnim rzędem widowni.

Ad b) Im wyższy poziom techniki wokalnej, czyli umiejętności operowania oddechem, wykorzystywania rezonatorów oraz właściwej emisji głosu, tym mniejsze problemy w artykułowaniu i łączeniu głosek. Dla publiczności oznacza to większy współczynnik zrozumiałości tekstu.

Ad c) Poziom zrozumiałości tekstu zmniejsza się w miarę podwyższania dźwięku. W górnych rejestrach następuje deformacja głosek. Zygmunt Pawłowski w pracy Podstawy foniatrii [2010] wyjaśnia następująco naturę tego zjawiska:

\begin{abstract}
„Kiedy śpiewaczka wykonuje np. sylabę na wysokości c3( dźwięk o częstotliwości podstawowej $\mathrm{F}_{\mathrm{o}}=1048 \mathrm{~Hz}$ ), zabraknie $\mathrm{w}$ takim przypadku dolnych formantów spółgłoski i samogłoski. W konsekwencji otrzymamy zniekształconą barwę głosek, co pogarsza ich zrozumiałość. Jest to powód (...) pogarszania się procentu zrozumiałości tekstu śpiewanego w miarę podwyższania dźwięku. Głosy żeńskie są wyższe niż męskie, dolne formanty głosek najczęściej zanikają podczas śpiewu kobiet, co powoduje mniejszą zrozumiałość tekstu śpiewanego.”
\end{abstract}

Problemy w artykulacji głosek w górnych rejestrach skali głosu w dużej mierze spowodowane są nieopanowaniem w pełni techniki wokalnej. [Pawłowski, 2005]

Ad d) Ważnym aspektem słyszalności jest nakierowanie fali głosowej w stronę słuchacza. Wszelkie odstępstwa skutkują obniżeniem słyszalności i zarazem zrozumiałości tekstu.

Ad e) Istotne jest, aby klasyfikacja głosu uwzględniała również jego rozpiętość dynamiczną: glosy o wyrównanej dynamice na całej skali głosu wykazują predyspozycje do wykonań na scenie operowej, natomiast głosy dysponujące dużą rozpiętością dynamiki mają większe szanse na powodzenie na scenach kameralnych. [Pawłowski, 2005]

Dodatkowo należy wspomnieć o dopasowaniu naturalnej głośności do wydolności głosu. Natura pracy śpiewaka, czyli np. konieczność przebijania się przez brzmienie orkiestry, może powodować nadwyrężanie głosu, przez co głoski tracą swoje cechy, a tekst staje się mniej wyrazisty 
lub niezrozumiały. Dźwięk wyemitowany piano musi być odpowiednio słyszalny dla widowni, a głoski wystarczająco wyraziste.

Ad. f) Podczas mowy artykulacja dominuje nad fonacją, a kanał głosowy jest mniej lub bardziej zamknięty. Odwrotnie dzieje się natomiast podczas śpiewu, gdzie to fonacja bierze górę nad artykulacją, a kanał głosowy jest otwarty. Podczas gdy artykulacja wymaga ruchów artykulatorów, zjawisko fonacji potrzebuje czasowego utrzymania ich pozycji $\mathrm{w}$ spokoju. [Bartmiński, 1993] Dlatego im więcej w języku odnotowanych subtelności $\mathrm{w}$ artykulacji głosek oraz zjawisk komplikujących wymowę, tym większe wyzwanie dla śpiewaka stanowi kwestia wymowy i dostarczenie treści słuchaczowi. [Miller, 1997] Samogłoski pod względem akustycznym, fizjologicznym oraz estetycznym były $\mathrm{w}$ muzyce zawsze bardziej faworyzowane i ma to związek z artykulacją i strukturą sylaby, a także naturalnym ideałem brzmienia. [Bristiger, 1986] Badania wykazują, że w języku polskim przeważają spółgłoski, a zatem $\mathrm{w}$ porównaniu $\mathrm{np} . \mathrm{z}$ językiem włoskim - językiem śpiewu, zrozumiałość tekstu śpiewanego $\mathrm{w}$ języku polskim będzie o wiele niższa. [Dukiewicz, za: Pawłowski, 2005]

Ad. g) Nieprawidłowa artykulacja oraz niestosowanie zasad wymowy scenicznej osłabia przekaz treści tekstu śpiewanego. [Pawłowski, 2010] Często można usłyszeć w wykonaniach np. zbyt otwarte $O$, które przez nadmierne obniżenie żuchwy nabiera cech $A$, czy też nieprawidłowe dzielenie lub łączenie dźwięków/sylab, co sprawia, że jesteśmy świadkami narodzin nowych słów. [Lasocki, Keldorfer za: Bartmiński, 1993]

Niemały wpływ na niezakłócony odbiór tekstu ma kwestia interpretacji i zrozumienia tekstu przez samego artystę, co pozostaje w ścisłym związku z wyrazistością i poprawnością artykulacyjną.

Ciekawa w tym kontekście jest wypowiedź G. Bebermeyera [za: Bristiger, 1986]:

„Słowa są nie tylko znakami dźwiękowymi; ich dźwięki uzmysławiają
raczej relacje, związki, ruchy mówiącego, skierowane do wewnątrz i na
zewnątrz. Przy czym spółgłoski służą w większej mierze opanowywaniu
uczuć, pojęciowemu urzeczowianiu widzialnego świata, podczas gdy
samogłoski swym wydźwiękiem sprzyjają bardziej rozbrzmiewaniu
wewnętrznego świata, subtelnej domeny związków emocjonalnych.”

Ad. h) Oprócz kwestii wymienionych w powyższych adnotacjach, istnieją inne czynniki, które mogą negatywnie wpłynąć na zrozumiałość tekstu w śpiewie. Będą to więc między innymi czynniki związane $\mathrm{z}$ zamianą $\mathrm{w}$ śpiewie prozodii językowej na prozodię muzyczną [Bartmiński, 1993], czyli np.: duże skoki interwałowe, akcenty muzyczne w opozycji do akcentów w mowie, bardzo wolne tempo - duże odległości między sylabami itd. 


\section{Wymowa sceniczna w śpiewie jako niezależna dziedzina naukowa}

W niniejszym artykule pragnę zwrócić uwagę na potrzebę istnienia osobnej dziedziny jaką jest wymowa sceniczna $w$ śpiewie. Jest to $\mathrm{w}$ Polsce dziedzina praktycznie niezbadana, ale o wielkim potencjale; jest traktowana trochę po macoszemu - w publikacjach polskich nagminnie łączona z emisją głosu, nauką śpiewu i interpretacją muzyczną (liryka wokalna). Wymowa sceniczna w śpiewie funkcjonuje za to jako niezależny przedmiot na uczelniach muzycznych np. w Stanach Zjednoczonych (diction).

Instruktorem wymowy scenicznej w śpiewie powinna być osoba intera właściwie multidyscyplinarna, łącząca wiedzę z zakresu językoznawstwa, historii języka, fonetyki, fonologii, zasad muzyki, historii muzyki, emisji głosu, dykcji oraz interpretacji.

Wymowa sceniczna, pomimo że bardzo ściśle związana z emisją głosu i interpretacją, nie zajmuje się bezpośrednio problemami tych dziedzin - to wyłącznie zbiór zasad dopasowanych do specyficznych warunków śpiewu, mających na celu osiągnięcie pełnej zrozumiałości tekstu oraz ułatwienie śpiewakowi artykulacji głosek, głównie poprzez poszerzenie wiedzy, uświadomienie procesów fonologicznych oraz odpowiednie ćwiczenia (artykulacja, trening wymawianiowy, transkrypcja itp.).

\section{Problemy i zadania}

\section{Legato}

W tzw. „polskiej” szkole śpiewu można napotkać dość popularną metodę łączenia fraz tekstu - jest to zasada sylab otwartych w celu maksymalizacji wybrzmienia samogłosek oraz uzyskania płynności i efektu legata.

I tak, fraza z pieśni Zasmuconej Mieczysława Karłowicza <chylisz główkę na pierś białą> według powyższych zasad powinna być wyartykułowana płynnie następującym sposobem:

\section{chy-li-szgłó-wkę-na-pie-rśbia-ła}

Nie zawsze jednak metoda ta pomaga śpiewakowi $\mathrm{w}$ osiągnięciu upragnionego idealnego efektu - tu: niebezpieczeństwem będzie stworzenie nowych sytuacji koartykulacyjnych oraz skutki w postaci zniekształceń głosek, odejście od znaczenia tekstu, a nawet powstawanie nowych znaczeń.

Kwestia niezagubienia a wyłonienia treści zamierzonej przez autora tekstu, a co za tym idzie zrozumiałości, jest sprawą pierwszorzędną.

Metoda ta zdecydowanie utrudniłaby artykulację we frazie wyśpiewywanej przez Chór Bohaterów w operze „Dzień świra” Hadriana Filipa Tabęckiego: $<$ jest cudownie>, gdzie wystąpiłoby nagromadzenie (klaster) przednich spółgłosek bezdźwięcznych z niewygodną tylną samogłoską <u> przy dość szybkim tempie muzycznym. 


$$
\text { je-stcu-do-wnie }
$$

W celu ułatwienia artykulacji może tu istnieć kilka rozwiązań - wybór najbardziej optymalnego jest kwestią indywidualną śpiewaka bądź do decyzji kierownika muzycznego.

Powyższe problemy są $\mathrm{w}$ istocie zadaniami dla instruktora wymowy scenicznej w śpiewie.

\section{Rodzaje problemów}

W swojej pracy, jako instruktor wymowy scenicznej w śpiewie, autorka napotkała na kilka powtarzających się podstawowych problemów pojawiających się u wokalistów, które utrudniają rozumienie przez słuchaczy tekstu śpiewanego:

a) wcześniej wspomniane kwestie związane ze zmianą znaczenia wyrazów, fraz czy zdań pod wpływem niewłaściwego łączenia wyrazów (dotyczy to nie tylko wymowy w językach obcych, ale nadzwyczaj często języka polskiego)

b) wątpliwości i trudności związane $\mathrm{z}$ artykulacją głosek na skutek dużego skoku interwału, niewygodnej wysokości dźwięku, długich/krótkich wartości nut, niewygodnych akcentów, wolnego/szybkiego tempa itp.

c) brak świadomości samego śpiewaka w kwestiach charakterystyki samogłosek i spółgłosek danego języka pod względem miejsca i sposobu artykulacji zarówno w teorii, jak i w praktyce (głównie ułożenie warg i języka)

d) ogólne zaniedbywanie sfery tekstowej (zarówno na poziomie artykulacji, jak i interpretacji i zrozumienia treści)

e) brak znajomości podstawowych zasad wymowy scenicznej zarówno w językach obcych, jak i w języku polskim.

(Dodatkowym utrudnieniem może być nieposiadanie przez wokalistę słuchu fonetycznego i/lub funkcyjnego.)

Problemy w wymowie różnią się i zmieniają w zależności od danego języka.

\section{Zadania instruktora wymowy scenicznej w śpiewie:}

1) Pilnowanie poprawności artykulacji spółgłosek i samogłosek (ze względu na miejsce i sposób artykulacji). Szczególnie trudne w opanowaniu są samogłoski mieszane, np. w wymowie francuskiej, niemieckiej czy angielskiej.

2) Znajomość zasad lączenia sylab, słów i fraz (głoski nieme, znaczenie wyrazów, dynamika, tempo)

Przykładowo $\mathrm{w}$ wymowie francuskiej nie wolno łączyć rzeczownika $\mathrm{w}$ liczbie pojedynczej za pomocą (niemej dotąd) spółgłoski z następującym 
wyrazem zaczynającym się na samogłoskę (a), należy natomiast łączyć rzeczownik po rodzajniku (b).

(a) <l'enfant / a peur > /lãfã a pœe/

(b) <les_hommes $>\quad /$ lez_om/

[Bernac, 1970 i Dictionnaire du française, 1999]

3) Sposób łączenia międzywyrazowego w śpiewie może być również podyktowane uzyskaniem zamierzonego znaczenia słów. Wyróżnić możemy łączenie postępowe (kiedy ostatnia spółgłoska staje się nagłosem następującej po niej sylaby) oraz wsteczne (kiedy ostatnia spółgłoska wykończona zostaje w zakresie swojej miary metrycznej i nie staje się nagłosem następującej po niej sylaby.

Np. <and my soul only sees >

ł. wsteczne: and my soul $\leftarrow$ only sees

tu: ł. postępowe - błąd: and my so $\rightarrow$ lonely sees

W przypadku braku oddechu pomiędzy słowami <soul> i <only>, /l/ należy postawić przed rozpoczęciem nowej miary w następnym takcie, nie powodując jednak cezury; w tym przypadku śpiewak prawdopodobnie zdecyduje się na rozpoczęcie słowa <only> $\mathrm{z}$ delikatnego zwarcia krtaniowego lub lekko zaakcentuje pierwszą sylabę $\mathrm{w}$ celu odcięcia znaczeń.

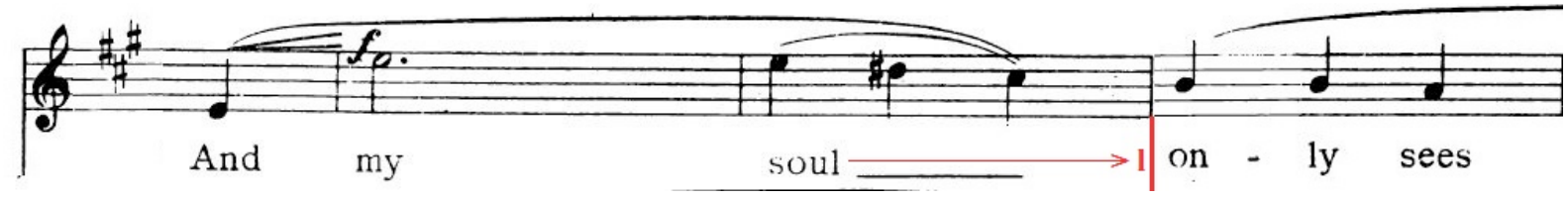

(fragment pieśni “Love-sight” z cyklu pieśni “The House of Life” Ralpha Vaughana Williamsa)

4) Zasady związane $\mathrm{z}$ dopasowaniem afektu, interpretacji oraz wizji artystycznej, np. w wymowie angielskiej możliwe jest użycie różnych alofonów w zależności od afektu, w celu podkreślenia emocji (np. namiętności, gniewu, tęsknoty)

5) Pilnowanie poprawnej realizacji geminat (podwójnych spółgłosek) jest ona różna $w$ różnych językach oraz wynika ze specyfiki i pochodzenia danego języka. Ma to również związek bezpośredni z podziałem na sylaby w danym języku.

6) Punktualność artykulacyjna a miary w takcie - w wielu językach możliwe jest rozpoczęcie realizacji spółgłoski (lub spółgłosek) rozpoczynającej sylabę jak z przednutką. Zabieg ten jest często 
podyktowany kategoriami wyrazu artystycznego lub w celu zwiększenia swobody artykulacyjnej.

7) Wymowa historyczna a wymowa współczesna; różne standardy języka, np.: w wymowie angielskiej, francuskiej czy niemieckiej.

8) Inne.

(opracowanie własne na podstawie LaBouff, 2008, Bernac, 1970, Michałowska, 1994 i in.)

\section{Podsumowanie i wnioski}

Wymowa sceniczna w śpiewie działa dwutorowo:

a) dostarcza zasad poprawnościowych wynikających z historii języka, tradycji wymawianiowych oraz charakterystycznych dla danego języka procesów artykulacyjnych.

b) zajmuje się rozwiązywaniem ogólnych i indywidualnych problemów wymawianiowych śpiewaków podczas pracy nad utworem wokalnym w danym języku.

Ze względu na bardzo skromne i niewystarczające źródła polskojęzyczne, niezbędne wydają się tłumaczenia obcojęzycznej literatury przedmiotu, badania aparaturowe nad polską wymową sceniczną w śpiewie i jej indywidualną specyfiką, jak również poszerzanie bazy danych $\mathrm{z}$ nagraniami (np. dla celów analizy progów zrozumiałości głosek w śpiewie (jakościowych i iloczasowych).

Ponadto, wiele pojęć i terminów w polskiej wymowie w śpiewie wymaga usystematyzowania i ujednolicenia. Interesująca wydaje się również kwestia problemów w polskiej wymowie scenicznej w śpiewie u śpiewaków niepolskojęzycznych. 


\section{Bibliografia}

Bartmiński, J. (1993) „Wymowa w śpiewie” w: Opuscula logopaedica, Lublin: UMCS, s. 226-231

Bernac, P. (1970) The Interpetation of French Song, Nowy Jork: Praeger Publishers

Bristiger, M. (1986) Związki muzyki ze słowem. $Z$ zagadnień analizy muzycznej, Warszawa: Polskie Wydawnictwo Muzyczne

Czechow, M. (1995) O technice aktora, Kraków: AKSHA

Klemensiewicz, Z. (1930) Prawidła poprawnej wymowy polskiej, Kraków: Gebethner i Wolff

LaBouff, K. (2008) Singing and Communicating in English. A Singer's Guide to English Diction, Oxford: Oxford University Press

Michałowska, D. (1994) O podstawach polskiej wymowy scenicznej, Kraków: Avalon Publishing Limited

Milewski, T. (1975) Językoznawstwo, Warszawa: Państwowe Wydawnictwo Naukowe

Nowakowski, P. (1997) Wariantywność wspótczesnej polskiej wymowy scenicznej, Poznań: Wydawnictwo „Sorus”

Pawłowski, Z. (2005) Foniatryczna diagnostyka wykonawstwa emisji głosu śpiewaczego i mówionego, Kraków: Oficyna Wydawnicza „Impuls”

Pawłowski, Z. (2010) Podstawy foniatrii dla osób duchownych, aktorów, nauczycieli i prawników, Warszawa: Wydawnictwo Salezjańskie

Rey-Debove, J. (1999) Le Robert \& CLE International. Dictionnaire du Francis, Paryż: Dictionnaires Le Robert \& CLE International

Tarasiewicz, B. (2006) Mówię i śpiewam świadomie, Kraków: TAiWPN UNIVERSITAS i Aneks

\section{Cytowane partytury}

Pieśń: Love-sight z cyklu pieśni The House of Life. A cycle of six sonnets by Ralph Vaughan Williams (C) Copyright ?? by West Central Printing Co. Ltd., London and Suffolk

\section{Tytuły cytowanych utworów}

Dzień Świra - opera w trzech aktach; Hadrian Filip Tabęcki

Pieśń: Love-sight z cyklu pieśni The House of Life. A cycle of six sonnets; Ralph Vaughan Williams

Pieśń: Zasmuconej (Chylisz główkę na pierś biała); Mieczysław Karłowicz 